\title{
The Implementation of Moodle in Online Learning during Covid-19 Pandemic: EFL Undergraduate Students' Perception
}

\author{
Fransiskus Jemadi \\ Universitas Katolik Indonesia Santu Paulus Ruteng
}

\{Ikinjemadi@gmail.com\}

\begin{abstract}
Education sector has been much affected by the presence of the Corona Virus Disease (COVID-19). The presence of the COVID-19 has brought tremendously significant shifts in teaching and learning process in higher education. The abrupt shift from in person contexts to remote learning has a huge impact in the way traditional higher education institutions deliver their courses to the students. This quantitative study seeks to uncover the undergraduate students' perception on their online learning during the COVID-19 pandemic period. Randomly selected, the present study involved ( $N=75$ students) from English Study Program Universitas Katolik Indonesia Santu Paulus Ruteng. The instrument used was a 4-point Likert Scale questionnaire which consisted of twenty closed-ended items. The results of the present study have discovered that students' perception towards the implementation of Moodle for their online learning was categorized as moderate level. The findings of this study have shed lights on pedagogical practices of teachers when implementing computer mediated learning tools in online class.
\end{abstract}

Keywords: Covid-19, MOODLE, Student's Perception, Online Learning

\section{Introduction}

The presence of the COVID-19 has brought tremendously significant shifts in teaching and learning process in higher education. As a response to this abrupt shift, most of the higher education institutions up to date are using web-based instruction system for teaching courses. This integration of web-based has been seen to be an alternative way in the mid of universities closure. Universitas Katolik Indonesia Santu Paulus Ruteng, for example, has had implemented online learning during the academic year 2020/2021 in response to the rapid spread of the Covid19 in region. This online learning is truly new both to the teachers and the students. As an initiative taken by the institution to minimize the spread of the virus, the institution applied asynchronous teaching and learning model. The lecturers and the students are required to use Moodle as a technological support to run the course. The adoption of technological support being integrated in the classroom seems to be effective when physical distancing is a must during the Covid-19 pandemic today.

The integration of technology in classroom have been highlighted by some researchers. The integration of technology provides a better and more interesting learning experience for both teachers and students (Fitriyadi, 2013), change the quality of learning (Lie et al., 2020), improve learning strategies (Jeng et al., 2010), and students engage in collaborative learning (Hsu \& Ching, 2013; Lai \& Wu, 2006). In addition, the use of technology in learning has a positive 
effect on the field of student learning. For example, technology has a positive impact on student literacy (Kim, Kil \& Shin, 2014), in the field of science (Crompton et al., 2016), in mathematics (Song \& Kim, 2015), in the field of history subjects (King, et. al., 2014), and in the arts (KatzBuonincontro \& Foster, 2013). Thus, the use of technology in teaching-learning activities contributes positively to students' achievement.

However, Supelveda-Escobar \& Morrison (2020), Scull, Sharma \& Garnier (2020) have asserted that mostly education sector had not been ready for the abrupt shift to off-campus teaching and was not well prepared for the challenge. Kidd and Murray (2020) asserted that teachers need to meet with calls for 'pedagogical agility' in the adoption of new practices in virtual schooling. In other words, teachers must be able to manage their online classes by using the available online technology supports. As they incorporate technology in their classes, teachers need to adapt to the new classroom management and have some set of pedagogical knowledge of online class in order to deliver the course materials effectively. In addition, they also need to develop students' enthusiasm in virtual class very well. At the same time, learners are obliged to master those online platforms in order they can learn the materials in virtual class as they have felt in previously in person classroom setting.

The sudden change of pedagogical practices in education due to the Covid-19 outbreak compels higher education to offer online teaching and learning as the alternative to face-to-face teaching and learning. Universitas Katolik Indonesia Santu Paulus Ruteng opts for adopting Moodle as an e-learning platform to run online classes during the Covid-19 outbreak. Aside from the use of Moodle, the lecturers at Universitas Katolik Indonesia Santu Paulus use other platforms such as Google Meeting or Zoom Meeting to create more effective online courses. The adoption of this e-learning platform might be because of some considerations. Ngoc \& Phung (2021) asserts that through Modular Object-Oriented Dynamic Learning Environment (MOODLE) learners can interact with each other synchronously on an online discussion board and engage in asynchronous discussions.

Zakaria \& Daud (2013) stated that MOODLE allows learners to be actively participating in the online learning process. It can be used as a tool for delivering content to students and to build rich collaborative learning communities. Moreover, other researchers discovered that digital support better engaged students in blended learning (Chiu, 2021), e-learning (Online Learning) based on computer webs is increasingly becoming one of the directions for the development of education (Yang \& Yuen, 2009) and stimulated an innovative stance (Ellis, Steadman \& Mao, 2020).

Albeit the advantages of using MOODLE, such as aforementioned above, there has been scarcity of studies on investigating the use of it in the context of Covid-19 outbreak and to the first-time users (lecturers or students) using it for their online classes. Since online learning is relatively new to the students, there might be some thoughts that they experience when using Moodle in their online class. Therefore, this study is intended to discover students' perception on using Moodle for their online classes.

\section{Research Methods}

The purpose of this study is to find out the EFL students' perception on the use of Moodle in online learning during COVID-19 pandemic. The researcher employed a descriptive quantitative research method through applying survey method. Students of English Department $(\mathrm{N}=75)$ at Universitas Katolik Indonesia Santu Paulus Ruteng involved in this study. They were 
chosen by applying purposive sampling technique. In order to gather data on EFL students' perception on the implementation of Moodle in their online class, the researcher deployed questionnaire as the instrument. The questionnaire was adopted from Zakaria \& Daud, (2013). The reason for the adoption is because the instrument's validity and reliability is 0.90 of Cronbach Alpha. In addition, using a 4-point likert scale, the questionnaire consists of twenty closed-ended statements which cover about the perceived usefulness, computer self-efficacy, perceive ease of use and attitude.

To collect the data, the researcher designed the questionnaire in form of URL link using Google Form and distributed it to the participants through WhatsApp platform in order to obtain the real data about their perception. Having gathered the data from the participants, the researcher analysed it using SPSS program in order to calculate the mean score of students' responses on the questionnaire. When the calculation of the mean score of students' responses to the questionnaire has been done, the researcher categorized the mean score as follows. The means score of $<1,65$ was considered as "low" level of perception, means score ranging between 1,66 and 3,35 were regarded as "moderate" level of perception, and means score of $>3,36$ or higher was reported as "high" level of perception.

\section{Results and Discussion}

\subsection{Finding}

The purpose of this study is to uncover the students' perception on the use of Moodle in online learning during COVID-19 pandemic. Therefore, in order to answer the research question, the researcher employed a descriptive quantitative research method through applying survey research design. The samples of this study were 75 students (47 males and 36 females) of English Department at Universitas Katolik Indonesia Santu Paulus Ruteng. The questionnaire was delivered to the samples from Tuesday, 20th April 2021 until Thursday, 10th June 2021. The responses from the students to the questionnaire are shown in the table 1.

Table 1: Students' Perception on Using MOODLE in online learning during COVID-19

\begin{tabular}{clcccccccc}
\hline No & \multicolumn{1}{c}{ Statements } & $\begin{array}{c}\text { SD } \\
1\end{array}$ & $\begin{array}{c}\text { D } \\
2\end{array}$ & $\begin{array}{c}\mathrm{A} \\
3\end{array}$ & $\begin{array}{c}\text { SA } \\
4\end{array}$ & $\mathrm{~F}$ & Score & Mean & Criteria \\
\hline 1 & $\begin{array}{l}\text { MOODLE helps me to } \\
\text { learn more efficiently }\end{array}$ & 0 & 0 & 43 & 32 & 75 & 257 & 3.43 & High \\
\hline 2 & $\begin{array}{l}\text { MOODLE improves my } \\
\text { academic performance }\end{array}$ & 4 & 25 & 35 & 11 & 75 & 203 & 2.71 & Moderate \\
\hline 3 & $\begin{array}{l}\text { MOODLE makes my } \\
\text { learning more effective }\end{array}$ & 0 & 10 & 40 & 25 & 75 & 240 & 3.20 & Moderate \\
\hline 4 & $\begin{array}{l}\text { MOODLE makes it easier } \\
\text { to learn at university }\end{array}$ & 0 & 2 & 40 & 33 & 75 & 256 & 3.41 & High \\
\hline 5 & $\begin{array}{l}\text { MOODLE gives me } \\
\text { control over my learning }\end{array}$ & 0 & 0 & 34 & 41 & 75 & 266 & 3.55 & High \\
\hline 6 & $\begin{array}{l}\text { MOODLE is advantageous } \\
\text { for my learning }\end{array}$ & 0 & 10 & 38 & 27 & 75 & 242 & 3.23 & Moderate \\
\hline 7 & $\begin{array}{l}\text { I can access the contents of } \\
\text { MOODLE }\end{array}$ & 0 & 20 & 33 & 22 & 75 & 227 & 3.03 & Moderate \\
\hline 8 & $\begin{array}{l}\text { I can freely navigate the } \\
\text { contents of MOODLE }\end{array}$ & 0 & 20 & 49 & 6 & 75 & 211 & 2.81 & Moderate \\
\hline
\end{tabular}




\begin{tabular}{llllllllll}
\hline No & \multicolumn{1}{c}{ Statements } & $\begin{array}{c}\text { SD } \\
1\end{array}$ & $\begin{array}{c}\text { D } \\
2\end{array}$ & $\begin{array}{c}\text { A } \\
3\end{array}$ & $\begin{array}{c}\text { SA } \\
4\end{array}$ & F & Score & Mean & Criteria \\
\hline 9 & $\begin{array}{l}\text { I can use MOODLE } \\
\text { without needing to be told } \\
\text { how it functions. }\end{array}$ & 0 & 10 & 47 & 18 & 75 & 233 & 3.11 & Moderate \\
\hline 10 & $\begin{array}{l}\text { I can solve problems that } \\
\text { arise on MOODLE. }\end{array}$ & 0 & 16 & 44 & 15 & 75 & 224 & 2.99 & Moderate \\
\hline 11 & $\begin{array}{l}\text { It is easy to get materials } \\
\text { from MOODLE }\end{array}$ & 0 & 0 & 30 & 45 & 75 & 270 & 3.60 & High \\
\hline 12 & $\begin{array}{l}\text { The process of using } \\
\text { MOODLE is clear and } \\
\text { understandable. }\end{array}$ & 0 & 21 & 43 & 11 & 75 & 215 & 2.87 & Moderate \\
\hline 13 & MOODLE is easy to use & 0 & 7 & 30 & 38 & 75 & 256 & 3.41 & High \\
\hline 14 & $\begin{array}{l}\text { Using MOODLE is an } \\
\text { attractive way to learn }\end{array}$ & 0 & 11 & 38 & 26 & 75 & 240 & 3.20 & Moderate \\
\hline 15 & I like using MOODLE & 0 & 0 & 10 & 65 & 75 & 290 & 3.87 & High \\
\hline 16 & $\begin{array}{l}\text { Learning using MOODLE } \\
\text { is fun }\end{array}$ & 0 & 12 & 35 & 28 & 75 & 241 & 3.21 & Moderate \\
\hline 17 & $\begin{array}{l}\text { Overall, I am able to use } \\
\text { MOODLE }\end{array}$ & 0 & 0 & 19 & 56 & 75 & 281 & 3.75 & High \\
\hline 18 & $\begin{array}{l}\text { Learning to use MOODLE } \\
\text { is easy for me }\end{array}$ & 0 & 0 & 48 & 27 & 75 & 252 & 3.36 & High \\
\hline 19 & $\begin{array}{l}\text { Using MOODLE is a good } \\
\text { idea }\end{array}$ & 0 & 0 & 39 & 36 & 75 & 261 & 3.48 & High \\
\hline 20 & $\begin{array}{l}\text { I can use MOODLE if } \\
\text { there are user manuals } \\
\text { available }\end{array}$ & 0 & 0 & 43 & 32 & 75 & 257 & 3.43 & High \\
\hline & \begin{tabular}{l} 
Total \\
\hline
\end{tabular} & & & & 1500 & 4922 & 3.28 & Moderate \\
\hline
\end{tabular}

Data displayed on the table 1 revealed that generally the students' perception on using MOODLE in online learning during COVID-19 pandemic is categorized as moderate (3.28). In addition, the four (4) subscales of students' perception, perceived usefulness, computer selfefficacy, perceived ease of use, and attitude, are described further in the following.

\section{Perceived Usefulness}

The students as the sample in this study were asked about their perception regarding the perceived usefulness of MOODLE in online learning during COVID-19 pandemic period. There were 6 statements for this item and the responses to the statements assessing perceived usefulness of MOODLE are shown in table 2.

Table 2: Perceived Usefulness of Using Moodle

\begin{tabular}{clcccccccc}
\hline No & \multicolumn{1}{c}{ Statements } & SD & $\begin{array}{c}\text { D } \\
1\end{array}$ & $\begin{array}{c}\text { A } \\
3\end{array}$ & $\begin{array}{c}\text { SA } \\
4\end{array}$ & F & Score & Mean & Criteria \\
\hline 1 & $\begin{array}{l}\text { MOODLE helps me to } \\
\text { learn more efficiently }\end{array}$ & 0 & 0 & 43 & 32 & 75 & 257 & 3.43 & High \\
\hline 2 & $\begin{array}{l}\text { MOODLE improves my } \\
\text { academic performance }\end{array}$ & 4 & 25 & 35 & 11 & 75 & 203 & 2.71 & Moderate \\
\hline 3 & $\begin{array}{l}\text { MOODLE makes my } \\
\text { learning more effective }\end{array}$ & 0 & 10 & 40 & 25 & 75 & 240 & 3.20 & Moderate \\
\hline 4 & $\begin{array}{l}\text { MOODLE makes it easier } \\
\text { to learn at university }\end{array}$ & 0 & 2 & 40 & 33 & 75 & 256 & 3.41 & High \\
\hline
\end{tabular}




\begin{tabular}{rlcccccccc}
\hline No & \multicolumn{1}{c}{ Statements } & SD & D & A & SA & F & Score & Mean & Criteria \\
\hline 5 & $\begin{array}{l}\text { MOODLE gives me } \\
\text { control over my learning }\end{array}$ & 0 & 0 & 34 & 41 & 75 & 266 & 3.55 & High \\
\hline 6 & $\begin{array}{l}\text { MOODLE is } \\
\text { advantageous for my } \\
\text { learning }\end{array}$ & 0 & 10 & 38 & 27 & 75 & 242 & 3.23 & Moderate \\
\hline Total & & & & 450 & 1464 & 3.26 & Moderate \\
\hline
\end{tabular}

Data displayed on the table 2 revealed that the students perceived the usefulness of MOODLE as moderate (3.26). In addition, pertaining to the usefulness of MOODLE on improving academic performance of the students, it revealed as the lowest mean score (2.71) and MOODLE gives the control over their learning reveled to be the highest mean score (3.55). Computer Self-Efficacy Pertaining to the students' perception on computer self-efficacy in online learning, their responses are displayed on table 3.

Table 3: Computer Self-Efficacy

\begin{tabular}{clcccccccc}
\hline No & \multicolumn{1}{c}{ Statements } & $\begin{array}{c}\text { SD } \\
1\end{array}$ & $\begin{array}{c}\mathrm{D} \\
2\end{array}$ & $\begin{array}{c}\mathrm{A} \\
3\end{array}$ & $\begin{array}{c}\mathrm{SA} \\
4\end{array}$ & $\mathrm{~F}$ & Score & Mean & Criteria \\
\hline 1 & $\begin{array}{l}\text { I can access the contents } \\
\text { of MOODLE }\end{array}$ & 20 & 33 & 22 & 75 & 227 & 3.03 & Moderate \\
\hline 2 & $\begin{array}{l}\text { I can freely navigate the } \\
\text { contents of MOODLE }\end{array}$ & 0 & 20 & 49 & 6 & 75 & 211 & 2.81 & Moderate \\
\hline 3 & $\begin{array}{l}\text { I can use MOODLE } \\
\text { without needing to be told } \\
\text { how it functions. }\end{array}$ & 0 & 10 & 47 & 18 & 75 & 233 & 3.11 & Moderate \\
\hline 4 & $\begin{array}{l}\text { I can solve problems that } \\
\text { arise on MOODLE. }\end{array}$ & 0 & 16 & 44 & 15 & 75 & 224 & 2.99 & Moderate \\
\hline 5 & $\begin{array}{l}\text { It is easy to get materials } \\
\text { from MOODLE }\end{array}$ & 0 & 0 & 30 & 45 & 75 & 270 & 3.60 & High \\
\hline 6 & $\begin{array}{l}\text { The process of using } \\
\text { MOODLE is clear and } \\
\text { understandable. }\end{array}$ & 0 & 21 & 43 & 11 & 75 & 215 & 2.87 & Moderate \\
\hline \multicolumn{1}{c}{ Total } & & & & & 450 & 1380 & 3.07 & Moderate \\
\hline
\end{tabular}

The data on table 3 revealed that the computer self-efficacy of the students was categorized as moderate (3.07). The only high category of students about their computer self-efficacy was about the easy access to get materials from MOODLE.

\section{Perceived ease of use}

Another aspect to be uncovered in this study was about students' perception about perceived ease of use of MOODLE in online learning during COVID-19 pandemic period. Their responses to the statements are displayed in the table 4.

Table 4: Perceived ease of use

\begin{tabular}{clcccccccc}
\hline No & \multicolumn{1}{c}{ Statements } & SD & D & A & SA & F & Score & Mean & Criteria \\
\hline 1 & MOODLE is easy to use & 0 & 7 & 30 & 38 & 75 & 256 & 3.41 & High \\
\hline 2 & $\begin{array}{l}\text { Using MOODLE is an } \\
\text { attractive way to learn }\end{array}$ & 0 & 11 & 38 & 26 & 75 & 240 & 3.20 & Moderate \\
\hline
\end{tabular}




\begin{tabular}{|c|c|c|c|c|c|c|c|c|c|}
\hline 3 & I like using MOODLE & 0 & 0 & 10 & 65 & 75 & 290 & 3.87 & High \\
\hline 4 & $\begin{array}{l}\text { Learning using } \\
\text { MOODLE is fun }\end{array}$ & 0 & 12 & 35 & 28 & 75 & 241 & 3.21 & Moderate \\
\hline \multicolumn{6}{|c|}{ Total } & 300 & 1027 & 3.42 & High \\
\hline
\end{tabular}

The table 4 revealed that the students' perception about the perceived ease of use of MOODLE was categorized as high (3.42). Liking of using MOODLE was perceived to be the highest mean score (3.87) and perceiving MOODLE as an attractive way to learn was lowest mean score (3.20).

\section{Attitude}

The students' attitude about using MOODLE in online learning during COVID-19 pandemic period is displayed in table 5 .

Table 5: Students' attitude towards using MOODLE

\begin{tabular}{llcccccccc}
\hline No & \multicolumn{1}{c}{ Statements } & SD & $\begin{array}{c}\text { D } \\
1\end{array}$ & $\begin{array}{c}\text { A } \\
3\end{array}$ & $\begin{array}{c}\text { SA } \\
4\end{array}$ & F & Score & Mean & Criteria \\
\hline 1 & $\begin{array}{l}\text { Overall, I am able to use } \\
\text { MOODLE }\end{array}$ & 0 & 0 & 19 & 56 & 75 & 281 & 3.75 & High \\
\hline 2 & $\begin{array}{l}\text { Learning to use } \\
\text { MOODLE is easy for } \\
\text { me }\end{array}$ & 0 & 0 & 48 & 27 & 75 & 252 & 3.36 & High \\
\hline 3 & $\begin{array}{l}\text { Using MOODLE is a } \\
\text { good idea }\end{array}$ & 0 & 0 & 39 & 36 & 75 & 261 & 3.48 & High \\
\hline 4 & $\begin{array}{l}\text { I can use MOODLE if } \\
\text { there are user manuals } \\
\text { available }\end{array}$ & 0 & 0 & 43 & 32 & 75 & 257 & 3.43 & High \\
\hline & Total & & & & 300 & 1051 & 3.51 & High \\
\hline
\end{tabular}

Data displayed on table 5 revealed that students' attitude towards the use MOODLE was high (3.51). In other words, they were able to use MOODLE as an online learning platform.

\subsection{Discussion}

Generally, the results of this study reveal that students have a moderate perception about the implementation of MOODLE for online learning during COVID-19 pandemic period at Universitas Katolik Indonesia Santu Paulus Ruteng. The two subscales of students' perception of online learning using MOODLE, perceived usefulness and computer self-efficacy, are categorized as moderate level of perception. On the other hand, the other two subscales, perceived ease of use and attitude, have been categorized as high level of perception.

The results of this study seem to be in line with the findings of other studies. For instance, Murillo, Hernández \& Rodríguez (2020), Chiu (2021), Chang \& Lan (2019) discovered that Moodle gave users a high degree of technological satisfaction, satisfying students' needs of digital support to better engage students in blended learning and a helpful learning method, respectively. The results obtained in this study and other studies confirm the theory that the perception of Moodle platform as easy to use or learn and has a positive influence on the intention to use it. In this case Escobar-Rodriguez \& Lozano (2012) stated that the Moodle platform presents no serious challenges to student use due to its similarity to other platforms with which they are already familiar with. 
Another interesting result of this study is the high perception level of students' perceived ease of use and attitude. It could be said that the implementation of Moodle contributes to students' performance during online learning. The possible explanation of this finding, as proposed by $\mathrm{Hu}$, et al. (1999), is that students are able to learn new technologies quickly and with less training than other populations because they are used to computers and to this kind of social media platforms. Consequently, studies conducted by Acar \& Kayaoglu, (2020), Gundu \& Ozcan, (2017), and Zakaria \& Daud, (2013) found that the use of MOODLE improved the students' learning and also the students' had positive perception on using MOODLE in online class.

However, the impediments of implementing e-learning to students have been highlighted by some researchers. Octaberlina \& Muslimin (2020) discovered that students experienced three barriers during online learning including unfamiliarity of e-learning, slow internet connection, and physical condition e.g. eye strain. In addition, viewed from the students' perspectives with respect to these obstructions, providing training to implement the LMS before the real class and giving break during the online class are of paramount. Another study which highlighted the impediments of online learning was conducted Coman, et.al (2020).

They discovered that higher education institutions in Romania were not prepared for exclusively online learning. There are some examples of unpreparedness of on line learning implemented in higher education in their studies, such as technical issues teachers' lack of technical skills and their teaching style improperly adapted to the online environment and students lack of interaction with teachers or poor communication with them. Similarly, Rodriguez \& Lozano (2012) stresses that higher education should pay more attention to the training aspect on the Moodle platform's usefulness for students and how it will enhance their productivity.

\section{Conclusion}

The aim of this study was to uncover the students' perception about the implementation of MOODLE for the online learning during the COVID-19 pandemic period. The results of the study found that students have moderate level of perception about the use of MOODLE. This study applied survey design and heavily rely on questionnaire to uncover students' perception about the implementation of MOODLE. Therefore, the researcher suggests the future research to apply another research method, qualitative study, use different data collection technique, interview, and involve the lecturers to be the participants of the study in order to gain comprehensive understanding about the implantation of e-learning in higher education.

\section{References}

[1] Acar, A., \& Kayaoglu, M. N. (2020). Moodle as a potential tool for language education under the shadow of covid-19. Eurasian Journal of Educational Research, 67-82.

[2] Chang, M. M., \& Lan, S. W. (2021). Exploring undergraduate EFL students' perceptions and experiences of a Moodle-based reciprocal teaching application. Open Learning: The Journal of Open, Distance and e-Learning, 36(1), 29-44.

[3] Chiu, T. K. (2021). Digital support for student engagement in blended learning based on selfdetermination theory. Computers in Human Behavior, 106909. 
[4] Coman, C., Țîru, L. G., Meseșan-Schmitz, L., Stanciu, C., \& Bularca, M. C. (2020). Online teaching and learning in higher education during the coronavirus pandemic: students' perspective. Sustainability, 12(24), 10367.

[5] Crompton, H., Burke, D., Gregory, K. H., \& Gräbe, C. (2016). The use of mobile learning in science: A systematic review. Journal of Science Education and Technology, 25(2), 149-160.

[6] Gundu, N., \& Ozcan, D. (2017). Implementation of the Moodle system into EFL classes. Profile Issues in TeachersProfessional Development, 19, 51-64.

[7] Sepulveda-Escobar, P., \& Morrison, A. (2020). Online teaching placement during the COVID-19 pandemic in Chile: challenges and opportunities. European Journal of Teacher Education, 43(4), 587 607.

[8] Ellis, V., Steadman, S., \& Mao, Q. (2020). 'Come to a screeching halt': Can change in teacher education during the COVID-19 pandemic be seen as innovation?. European Journal of Teacher Education, 43(4), 559-572.

[9] Escobar-Rodriguez, T., \& Monge-Lozano, P. (2012). The acceptance of Moodle technology by business administration students. Computers \& Education, 58(4), 1085-1093.

[10] Fitriyadi, H. (2013). Integrasi teknologi informasi komunikasi dalam pendidikan: potensi manfaat, masyarakat berbasis pengetahuan, pendidikan nilai, strategi implementasi dan pengembangan profesional. Jurnal Pendidikan Teknologi dan Kejuruan, 21(3).

[11] Lie, A., Tamah, S. M., Gozali, I., Triwidayati, K. R., Utami, T. S. D., \& Jemadi, F. (2020). Secondary School Language Teachers' Online Learning Engagement during the COVID-19 Pandemic in Indonesia. Journal of Information Technology Education: Research, 19, 803-832.

[12] Hsu, Y. C., \& Ching, Y. H. (2013). Mobile app design for teaching and learning: Educators' experiences in an online graduate course. International Review of Research in Open and Distributed Learning, 14(4), 117-139.

[13] Hu, P., Chau, P., Sheng, O., \& Tam, K. (1999). Examining the technology acceptance model using physician acceptance of telemedicine technology. Journal of Management Information System, 16(2), 91-112.

[14] Katz-Buonincontro, J., \& Foster, A. (2013). Integrating the visual arts back into the classroom with mobile applications: Teaching beyond the "click and view" approach. Journal of Digital Learning in Teacher Education, 30(2), 52-59.

[15] Kidd, W., \& Murray, J. (2020). The Covid-19 pandemic and its effects on teacher education in England: How teacher educators moved practicum learning online. European Journal of Teacher Education, 43(4), 542-558.

[16] Kim, H. S., Kil, H. J., \& Shin, A. (2014). An analysis of variables affecting the ICT literacy level of Korean elementary school students. Computers \& Education, 77, 29-38.

[17] King, L. J., Gardner-McCune, C., Vargas, P., \& Jimenez, Y. (2014). Re-discovering and re-creating African American historical accounts through mobile apps: The role of mobile technology in history education. The Journal of Social Studies Research, 38(3), 173-188.

[18] Lai, C. Y., \& Wu, C. C. (2006). Using handhelds in a Jigsaw cooperative learning environment. Journal of Computer Assisted Learning, 22(4), 284-297.

[19] Murillo, G. G., Novoa-Hernández, P., \& Rodríguez, R. S. (2020). Technology Acceptance Model and Moodle: A systematic mapping study. Information Development, 0266666920959367.

[20] Ngoc, T. P., \& Phung, L. T. K. (2021, March). Online Language Learning via Moodle and Microsoft Teams: Students' Challenges and Suggestions for Improvement. In 17th International Conference of the Asia Association of Computer-Assisted Language Learning (AsiaCALL 2021) (pp. 106-113). Atlantis Press.

[21] Octaberlina, L. R., \& Muslimin, A. I. (2020). EFL Students Perspective towards Online Learning Barriers and Alternatives Using Moodle/Google Classroom during COVID-19 Pandemic. International Journal of Higher Education, 9(6), 1-9.

[22] Scull, J., Phillips, M., Sharma, U., \& Garnier, K. (2020). Innovations in teacher education at the time of COVID19: an Australian perspective. Journal of Education for Teaching, 46(4), 497-506.

[23] Song, D., \& Kim, P. (2015). Inquiry-based mobilized math classroom with Stanford mobile inquirybased learning environment (SMILE). Mobile learning and STEM: Case studies in practice, 150-161. 
[24] Yang, H. H., \& Yuen, S. C. Y. (Eds.). (2009). Handbook of Research on Practices and Outcomes in E-Learning: Issues and Trends: Issues and Trends. IGI Global.

[25] Zakaria, E., \& Daud, M. Y. (2013). The Role of Technology: MOODLE as a Teaching Tool in a Graduate Mathematics Education Course. Asian Journal of Management Science \& Education, 2(4), 46-52. 